日本皕床麻酔学会第28 回大会パネルディスカッション

小児麻酔におけるリスクマネジメント

小児麻酔におけるリスクマネジメント：術前評価

香川哲郎* 鈴木 毅* 高辻小枝子* 大西広泰* 池島典之*

[要旨］小児麻酔における偶発症は新生児・乳児で多く，麻酔管理が原因となるもの のうちでは高度低酸素血症が多いことが特徵である. 小児の術前評価は, 小児特有の リスクを把握し, 偶発症を予防するための最初のステップとしてリスクマネジメント 上重要である. 小児の術前評価には小児麻酔や小児についての知識および経験が必要 であるが, 麻酔科医, 外科医, 小览科医や看護師などスタッフ間の良好な連携や, 親 やこどもとの十分なコミュニケーションとそれを可能にする診察スペースなども重要 な役割を果たす.さらに得られた情報を共有し, 発生しうるリスクについて準備, 対 応することが事故を予防することにつながると考えられる.

キーワード: 小児麻酔, 術前診察, リスクマネジメント, コミュニケーション

(日臨麻会誌 Vol.29 No.3, 250 257, 2009)

\section{I リスクマネジメントと術前評価}

リスクマネジメントとは, リスクを把握・特定し， その影響度と発生頻度を考慮して対策を講じて事故 を予防し, 事故が発生した際には被害を最小限に抑 えるプロセスをいう。リスクマネジメントの観点か らは, 術前評価は麻酔にかかわるリスクを最初に把 握・特定するステップであり, リスクが特定されれ ばそれに対する対策を立て，準備をして麻酔を行う ことで, 被害, すなわち合併症や医療事故を最小限 に抑えることができる. 小児麻酔においては，例え ば術前の診察で患児が上気道炎に罹患していること が判明すれば，予想されるリスクとして周術期の酸 素飽和度低下，喉頭痤攣，気管支痤攣などがあげら
れ, 手術の延期, 気道確保法の再考, 十分経験のあ る麻酔科医が担当する，などの対応を前もってとる ことができるように, 術前評価は大変重要である.

\section{II 偶発症例調査からみた小览麻酔のリスク}

日本麻酔科学会による「麻酔関連偶発症例調査 $2000\lrcorner^{1)}$ によと, 年龃区分ごとの全偶発症発生率 (心停止, 高度低血圧, 高度低酸素血症, その他を 合計したもの) (図1)は1万症例当たり 1 力月以下で は 70.04 と最も高く, 12 力月以下でも 42.06 と高くな っている。一方 5 歳以下，18歳以下の偶発症発生率 は他の年齢群に比べて低い。 また全偶発症の原因別 発生率(図2) は，1 カ月以下では「術前合併症が原 因」が最も高く, 次いで「手術が原因」,「麻酔管理 


\section{偶発症発生率(対 1 万症例)}

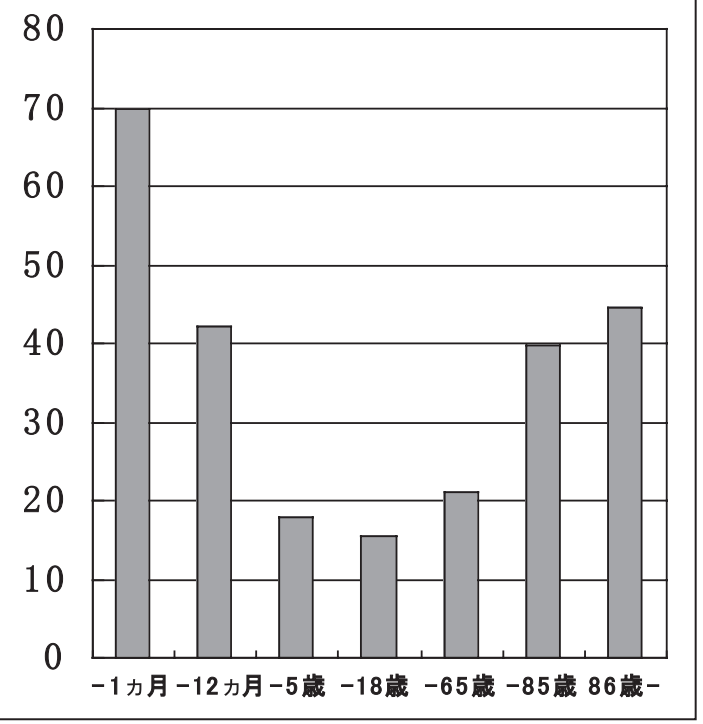

図 1 年齢区分ごとの全偶発症発生率

が原因」の順である一方，12 カ月以下，5歳以下で は「麻酔管理が原因」が最も高く, 次いで「術前合 併症が原因」,「手術が原因」の順となっている。 「麻酔管理が原因」の占める割合は, この 12 カ月以 下と 5 歳以下では他の年齢群に比べて高い. また， 「麻酔管理が原因」で発症する偶発症では高度低酸 素血症が最も多く, 心停止, 高度低血圧は少なくな っている。より新しい報告である「麻酔関連偶発症 例調査 2005$\lrcorner^{2)}$ でも, 1 力月以下の偶発症発生率は 1 万 症例当たり 31.7 と, 低下しているものの依然高い.

これらのことから，1カ月以下および 12 力月以下 の小児(新生児および乳児)では麻酔関連の偶発症の リスクが高く, 特に 1 カ月以下(新生児)では, 術前 合併症および手術の内容についてょく理解しておく ことが必要である。新生児期手術が必要な症例は重 篤な疾患, 先天性心疾患などが多く含まれ, 偶発症 に遭遇する可能性が高いことを反映している，新生 児では緊急手術が多く術前合併症・術式について調 べるための時間に制約があることを考えると, 新生 児が対象となるような手術については普段から勉強 しておき，短時間で問題点をあげることができるよ
うにしておかなければならない。

一方，新生児以降の小児では「麻酔管理が原因」 が多いこと, 特に 5 歳以下のように偶発症発生率が 低いなかでも「麻酔管理が原因」が多いこと，内訳 として「高度低酸素血症」が多いことは，小児はた とえ全身状態が良くても酸素消費量が大きい, 機能 的残気量が少ない, 解剖学的に気道閉塞を起こしゃ すいなどの理由から容易に低酸素血症に陥りやすい こと, 喉頭痤攣, 気管支痤攣，低換気などの呼吸 器系のトラブルが多いことを反映しているとみら れ，術前評価においては気道や呼吸について十分 に診察, 検討し麻酔管理に役立てることが重要とい える。

\section{III 術前評価の流れ}

これまでに述べたように, 術前診察で得られる情 報はリスクマネジメント上重要である。 小児の診察 を行うためには小児特有のリスクについてあらかじ め知っておくことや，小児を怖がらせない技術など が必要である。一般の麻酔科医が小児と接する機会 は多くないかもしれないが，こうした知識や技術の 不足については, 教科書などから知識を得, 指導医 や小児科医などに適宜コンサルトすることで補うこ とができる。また患児本人から得られる情報は限ら れているため, 親や術者からも情報を得ることが必 要である。こうして得られた情報を周術期にかかわ る医療スタッフ間で共有することで, 患者の安全を 担保するためのチーム医療の輪ができる.

すなわち，術前評価を行いそれを生かすには知識 のみならずコミュニケーションも重要である，親， こども, さらには術者, 小児科医, 看護師等と十分 コミュニケーションを取り，短時間で多くの情報を 集め, それを共有することでリスクを減らすことを 術前評価の目標とする。以下, 親, こども, 術者か ら集める情報のポイントと, 麻酔の説明・同意など について順次述べる。 


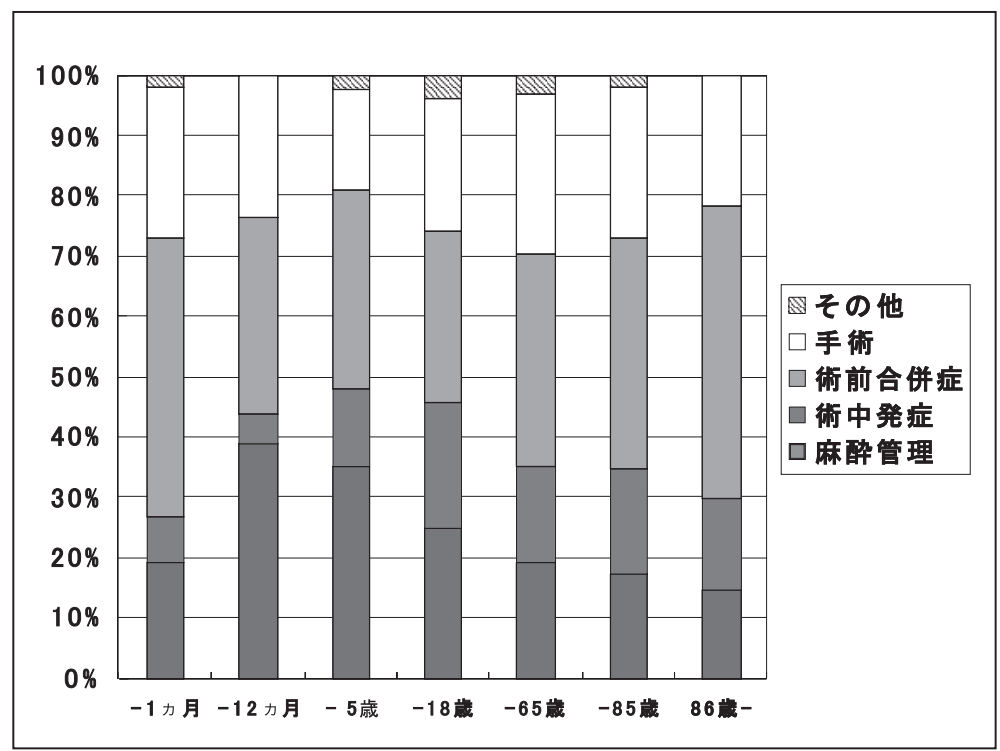

図2 全偶発症の原因別発生率

\section{表 1 親からの情報}

・一般的な問診, 病歴, 日常の状態の確認

- 出生時の状況 (在胎週数と受胎後週数, 出生体重, 分婏異常, 挿管・人 工呼吸歴など)

・かぜ，喘息，クループなど呼吸器疾患

・アレルギー

・内服薬(抗凝固薬, ステロイド, 抗痙攣薬など)

- 既往歴, 以前の麻酔歴, 家族歴 (悪性高熱症, 神経筋疾患, 喘息, 前投 薬の効き具合, 麻酔薬への反応など）

・最終経口摂取時間

·予防接種歴, 感染症罹患歴, 周囲の感染症の流行と接触歴

\section{IV＼cjkstart親からの情報}

親から集める情報としては表1のようなものがあ る。未熟児出生 (早産, 低出生体重) は無呼吸や呼吸 障害と関連が強く, 確認しておく必要性が高い. 在 胎週数と受胎後週数は, 短いほど術後の無呼吸の可 能性が高い $(\text { 図3 })^{3)}$. 多くは受胎後 46 週以下で発生 しているが，60週でも報告されている。 また貧血 (ヘマトクリット<30\%)があれば週数にかかわらず 無呼吸のリスクが存在する。小児では鼠径へルニア 手術などに対して日帰り手術を行っている施設もあ るが，こうした患者は入院手術とし，46〜60週を
超えるまで延期する，麻薬の使用を控える，術後無 呼吸モニターをつける，などの体制が必要である。 在胎 28 週で出生すれば，生後 3 力月で 40 週， 8 力月 でようやく 60 週となることから，未熟児出生児の 日帰り手術は安全域を見越せば生後 1 年ぐらいは行 わない方がよいということになる。

挿管・人工呼吸歴がある場合, 気管支肺異形成 (bronchopulmonary dysplasia：BPD)を含めた慢性 肺疾患の有無や声門下狭窄の有無に注意する。 BPD では未熟肺に対する挿管，人工呼吸，酸素投与から 肺胞破壞, 間質線維化をきたす。気道過敏性充進, 肺のコンプライアンス低下がみられ, 容易に低酸素 


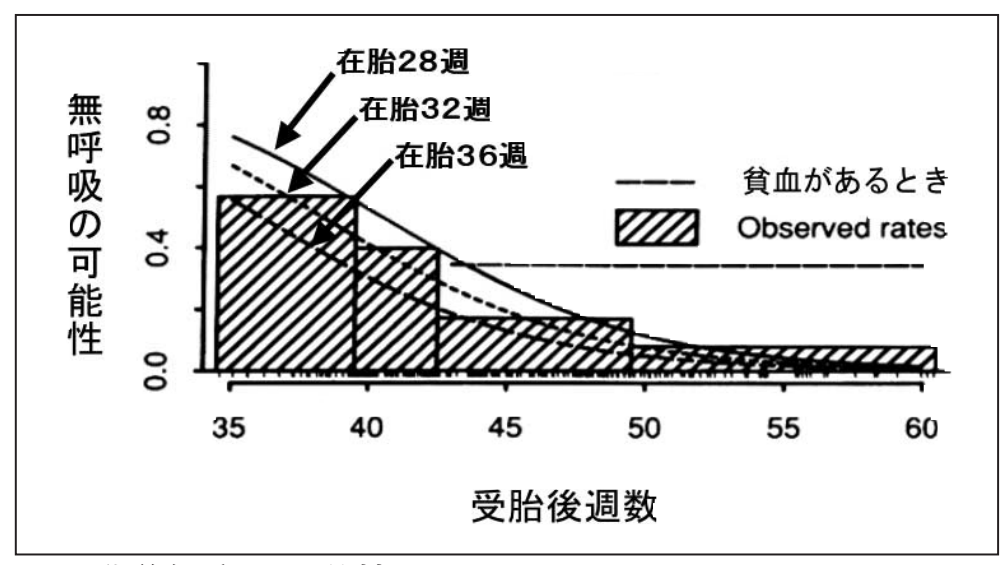

図3 術後無呼吸の可能性

在胎週数が短いほど, 受胎後週数が短いほど術後の無呼吸の可能性 が高い.

〔文献3)より引用・改変]

血症, 高炭酸血症になる, 人工呼吸時は高気道内圧 を必要とする，麻薬で容易に呼吸抑制をきたす，術 後無呼吸をきたしやすい, 呼吸器感染から呼吸不全 になりやすいなどのリスクがある，可能であれば手 術は生後 1 年を過ぎてから行う, 人工呼吸時は呼気 時間を長くとる，術後呼吸抑制をきたす薬物を控え る，気管支拡張薬などを継続する，などの対応がと られる。

声門下狭窄は無症状であることがあり，挿管の際 に初めて気がつかれることもある。わずかな浮腫で 喘鳴，呼吸困難をきたすことがあるため，チューブ を無理に進めず，細めのチューブでリークがあるこ とを確認し, 術後の狭窄症状の増悪がないかどうか の観察が必要となる.

かぜをはじめとする上気道感染症は小児では頻繁 にみられる。周術期低酸素血症, 気道分泌過多, 喉 頭痤攣，気管支痤攣，無気肺，肺炎などのリスクが あり，また，より重篤な病気(インフルエンザ， RS ウイルス肺炎，心筋炎や脳炎など）の前兆のことも あるため慎重な対応が必要である。対応として急性 期, 悪化傾向, 発熱, ラ音, 喘鳴があれば中止とし, できれば 6 週間，少なくとも 2 週間は延期したいと ころである。しかし軽度の鼻汁が続いているが元気 で発熱もないような場合は中止するべきかどうか迷
うことも多く，また麻酔科医の一存で中止すると親 や外科医からクレームがつくことさえある。麻酔科 医は患児の利益を優先しつつも，家族が手術に合わ せて休みを取れるかどうかなどの事情や，手術の急 ぎ具合なども考慮し, 麻酔のリスクを説明して納得 のうえで決定することが望ましい. 中止しない場合, リスクに対する準備として，低酸素血症には酸素投 与，喉頭痤攣にはマスクによる PEEP や筋弛緩薬， 分泌過多には挿管して吸引，あるいは慣れた麻酔科 医が対応するなどの配慮が必要となる ${ }^{4)}$.

喘息やてんかんなど小児によくみられる合併症の 程度とコントロール状態を確認することも重要であ り，小児科からの情報が有用である。また予防接種 歴や感染症の罹患歴，感染症患児との接触歴を確認 する ${ }^{5)}$. 予防接種から一定期間空けることで副反応 との鑑別を容易にするとともに，院内への水痘やイ ンフルエンザなどの感染症の持ち込みや，入院中の 感染症の発症を防ぐ。

小児では繰り返し手術を受ける場合も多く，以前 の麻酔に伴う合併症，不安の程度，前投薬の効き具 合，術後の疼痛とそれに対する反応などを確認する。 無理な導入により不快な経験をすると以後の診察や 麻酔に難渋することがあるが，麻酔導入を嫌がる反 応は術前診察で予想・対応可能であり，こども本人 
表2 こどもからの情報

・全身状態・発達の程度

・母子分離の程度 (特に 6 力月〜 6歳ごろ), 不安の程度

・上気道(いびき, 扁桃肥大, 小顎, 開口障害, 動摇歯など)

・呼吸器系 (かぜ, 上気道炎, 喘息, 呼吸障害, 胸郭変形など)

・循環器系 (心疾患, 心雑音, チアノーゼ, 化学療法など)

・体表・皮膚・粘膜の所見 (脱水, チアノーゼ, 発疹など)

・局所麻酔に関連する部位の確認

表3 術者, 小児科医からの情報

・基礎疾患, 症候群, 全身状態など普段のコントロール状態

・術式, 体位, 手術時間

・予想出血量

・手術侵襲, 術後の痛みの程度

にも年齢に応じた説明を行ったうえで麻酔を行うこ とが求められる。

\section{Vこどもからの情報}

実際にこどもを診察する場合，表2にあげるよう な事項に注意し，優しく，こどもにフレンドリーで， かつ短時間で要領よく行うようにする。体重や身長, 発達の程度が年齢相当であるかを確認する。視診で 表情，顔色，チアノーゼや黄疸を見る．泣きだす前 に聴診を先に行い，まず心音，次いで呼吸音を聞く。 上気道や咽頭の視診は最後となる。仙骨麻酔，硬膜 外麻酔を行うなら背部の聴診のついでに穿刺部位も 確認しておく.

気道に関する情報は小児では特に重要である。呼 吸のパターンを確認し, 呻吟, 喘鳴, 陥没呼吸, 努 力呼吸などの有無を見る．乳歯の動摇の有無を確認 する．親に睡眠時のいびきや無呼吸を確認し，扁桃 肥大の大きさを確認する。慢性の肺疾患や上気道閉 塞があれば胸郭変形(漏斗胸や鳩胸)がみられること がある。 小顎，巨舌，開口障害，後屈障害などは頻 度の高いものではないが，各種先天奇形症候群や口 唇口蓋裂，小耳症などでよくみられる。これらすべ てはマスク換気困難，扦管困難，周術期の上気道閉
塞のリスクにつながる.

先天性心疾患については，軽症の患者，幼児期以 降の患者の多くがこれまでの検診などで指摘されて おり詳細が判明していることが多いと思われるが， 新生児，乳児でははっきりしていないこともありう る、検診などで異常を指摘されたことがないか確認 を行う。麻酔科医にとって小児の心雑音の判定は容 易ではない．周術期のリスクとなる病態が疑われれ ば心エコー検査を含めて小児科医(できれば小児循 環器内科医)にコンサルトする，悪性疾患の治療を受 けている患児ではアントラサイクリン系化学療法剤 投与後の心機能障害がみられることがあり，小児科 医や術者に確認しておく。

\section{VI＼cjkstart術者，小巟科医からの情報(表 3)}

患児の全身状態や既往疾患にかかわることでは, 普段フォローしている小児科医からの情報が有用で ある．先天奇形症候群については麻酔管理上注意す べき点が多いため，成書 $\left.{ }^{6}\right)$ などで麻酔との関連を調 ベておく

小児の手術は鼠径へルニアなど定型的なもの以外 については一般にバリエーションが豊富であり，術 式，体位，手術時間，予想出血量などを術者に確認 


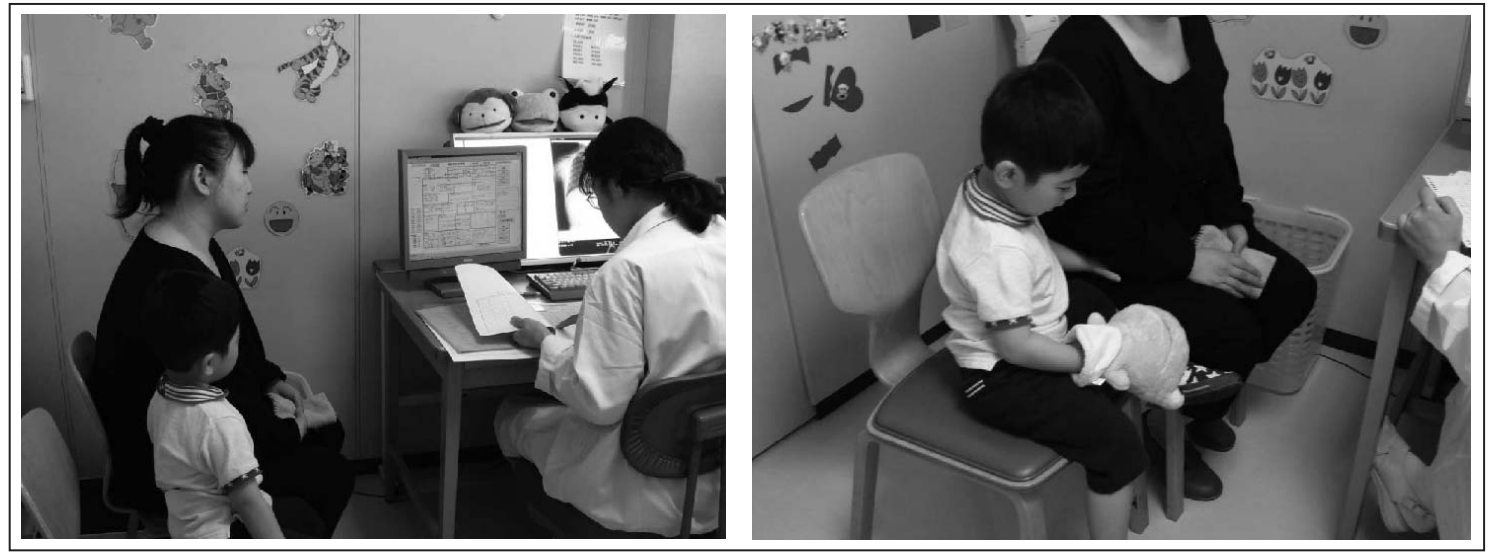

図4 兵庫県立こども病院の麻酔科術前診察外来

する、麻酔法, 鎮痛法, 気道確保法, モニターなど 麻酔プランすべてにかかわる。例えば小児では術中 に出血が多くなってきても後から静脈路や観血的動 脈圧を追加する，といったことが困難である。術者 とよくコミュニケーションを取っておき, 手術室ス タッフとともに十分な準備をしておくことがリスク の軽減につながる。

\section{VII 麻酔の説明と同意}

小児麻酔では親に対して麻酔の説明をし，同意を 得ることで, こどもとともに親の麻酔に対する不安 を軽減するように努める。こども本人にも理解度に 応じて話をするが, 親の口からも「麻酔(や入院, 手術)は怖いものではない」「眠っている間に終わる」 という話をしてもらうことでこどもは安心する。そ うすれば緩徐導入や後の治療にも協力的になること が多い.

親に麻酔の説明をしている最中にこどもが泣いた りするとそちらに気を取られて十分な話ができない こともある. 看護師の協力を得ながら, 短時間で理 解が得られるよう説明書, 絵, 写真などを用いて工 夫することが望ましい. われわれの施設では, 一般 的な麻酔や手技に伴う危険性・合併症に加えて, 気 管挿管に伴うもの (口腔, 歯の損傷など), 緊急手術 に伴うもの(誤嚥など), 硬膜外麻酔に伴うもの(頭
痛, 血腫, 神経障害など), カテーテル挿入に伴う もの(血腫，気胸など), 麻酔薬などに対するアレル ギー反応，悪性高熱症などについても文書を用いて 説明している．頻度が低いが重篤であるものについ てはきわめてまれであることも伝えて，過度に不安 をあおることのないようにしている。

\section{VIII 兵庫県立こども病院の術前診察外来}

兵庫県立こども病院 (以下，当院)では，手術症例 の約 9 割に当たる症例において麻酔科専用の独立し た診察室で術前診察を行っている. 診察室はこども が親しみやすい環境とし，親が話している間はこど もが遊んでいられるようにするなど，緊張させない 工夫を取り入れている(図4).

患者のベッドサイドなどではなく独立した診察室 で術前診察を行うことは, 患者・家族との接触の機 会が少ない麻酔科医や手術室看護師にとってコミュ ニケーションや相互理解, 信頼を得ることに有効と 考えられる.プライバシーが配慮され, 落ち着いて 診察できることで親も麻酔科医も話をしやすい. ま た入院日に麻酔科医が診察し, 入院の可否を決定す ることができる(種々の入院手続きを踏んだ後でキ ヤンセルとなり帰ってもらうことが少ない), 麻酔 科医の手が空くまで親が病棟で麻酔科医を待つ必要 がない, 経験のある麻酔科医を診察担当医とするこ 


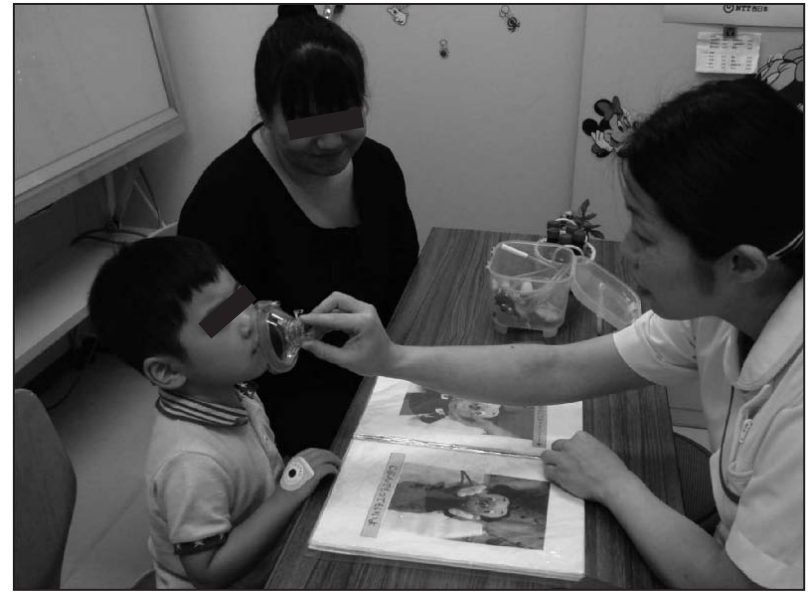

図 5 術前のオリエンテーション(プレパレーション) マスクをつけて呼吸する練習をしてもらう。

とでリスクの見落としが減る，などの利点があり， 患者側にも医療者側にもメリットが大きい. 看護師 は診察の介助とともに, 泣いている患児をあやした りして親が医師の話をゆっくり聞けるように配慮し ている。また看護師がこどもに対して絵本を用いた オリエンテーションを行い, マスクの練習やマスク につける香りを選んでもらうなど，麻酔・手術のプ レパレーションを行っている(図5)。これにより親 もこどもも安心するとともに，看護師はそのときの こどもの様子を観察し, 実際の入室の際の対応など に役立てている。麻酔科医からすると, 看護師の支 援を得ながら落ち着いて診察できることは小児の診 察を行う際には非常に助けになっている。

欠点としては, 診察担当のために麻酔科医, 看護 師ともマンパワーが必要であること, 診察担当医と 麻酔担当医は通常異なるため, 麻酔担当医への確実 な申し送りが必要であることである。申し送りにつ いては，術前診察情報を既定のフォーマットでパソ コンに入力し, 担当麻酔科医や看護師が参照でき, かつ電子麻酔記録からも参照可能なしくみを作って いる. 電子カルテもしくは手術予約システムなどが あれば十分対応可能であると考える。また麻酔科内 で毎朝カンファレンスを行い情報交換できるように している.

\section{まとめ}

小児の術前評価は, 小児特有のリスクを理解・把 握する最初のステップとして, リスクマネジメント 上重要である。多様なリスクを，こどもに会ってか ら短時間で把握するためには小児麻酔や小児につい ての知識および経験が必要であるが，麻酔科医，外 科医，小児科医や看護師などスタッフ間の良好な連 携や，親やこどもとの十分なコミュニケーションと それを可能にする診察スペースなどにより補うこと が可能である。さらに得られた情報をスタッフ間で 共有し，発生しうるリスクについて準備，対応する ことが事故を予防することにつながると考えられる。

\section{参考文献}

1）森田潔, 川島康男, 入田和男ほか：「麻酔関連偶発症例 調查 $2000 」 に つ い て ：$ 年齢区分別集計一(社) 日本麻醉 科学会安全委員会手術室安全対策専門部会報告一。麻醉 $51 ： 1285-1296,2002$

2）入田和男, 津崎晃一, 讃岐美智義ほか: 危機的偶発症 発生率に低下傾向：危機的偶発症に関する麻酔関連偶発 症例調查 2005 の速報と最近 5 年間の推移一(社) 日本麻醉 科学会安全委員会偶発症例調查ワーキンググループ報 告一. 麻醉 $56 ： 1433-1446,2007$

3) Coté CJ, Zaslavsky A, Downes JJ, et al. : Postoperative apnea in former preterm infants after inguinal herniorrhaphy. A combined analysis. Anesthesiology 82 : 809822, 1995

4) Coté CJ : 小児麻酔, ミラー麻酔科学. Miller RD 編, 武田純三監修.メディカル・サイエンス・インターナシ ヨナル, 東京, 2007, 1839-1868

5）香川哲郎：予防接種，臨床小児麻酔ハンドブック（改訂 第2 版). 前川信博監修。診断と治療社, 東京, 2008 , 133-134

6) Baum VC, O'Flaherty JE : Anesthesia for Genetic, Metabolic, and Dysmorphic Syndromes of Childhood, 2nd ed. Lippincott Williams \& Wilkins, Philadelphia, 2006 


\title{
Preoperative Evaluation
}

\author{
Tetsuro KAGAWA, Takeshi SUZUKI, Saeko TAKATSUJI, \\ Hiroyasu ONISHI, Noriyuki IKEJIMA
}

Department of Anesthesiology, Hyogo Prefectural Kobe Children's Hospital

The incidence of life-threatening events in pediatric anesthesia is highest in neonates and infants. Among such events, hypoxia is frequently caused by poor anesthetic management. Preoperative evaluation of pediatric patients is an important first step in risk management in order to understand child-specific risks and to prevent life-threatening events. Preoperative evaluation of pediatric patients requires sufficient knowledge and experience in pediatric anesthesia as well as cooperation among anesthesiologists, surgeons, pediatricians and nurses, good communication with patients and their parents, and rooms reserved for preoperative examination which make such communication possible. In addition, it is believed that appropriate preparation based on shared information concerning risk factors may prevent such events from happening.

Key Words : Pediatric anesthesia, Preoperative examination, Risk management, Communication

The Journal of Japan Society for Clinical Anesthesia Vol.29 No.3, 2009 